\title{
A method for determining the stability of lysosomal membranes in the digestive cells of Mytilus edulis
}

\author{
Shiyong Lin ${ }^{1, *}$, David J. Steichen $\mathrm{Jr}^{1,2}$ \\ ${ }^{1}$ Coastal Research Center and Marine Science Institute and ${ }^{2}$ Department of Biological Sciences, \\ University of California, Santa Barbara, California 93106, USA
}

\begin{abstract}
Fractionation- and filtration-based methods were compared to establish the more appropriate technique for determining the stability of lysosomal membranes in the digestive cells of the mussel Mytilus edulis. Mussels were exposed to air for $5 \mathrm{~d}$ (termed hypoxic stress), at which time their digestive glands were removed. Homogenized tissue samples were prepared using 2 methods: filtration and the standard mammalian technique of fractionation by centrifugation. Specific activities of acid phosphatase and lysosomal membrane-linked latency of hydrolases were determined. A significant effect of hypoxia on latency was observed in the filtered preparation but not the fractionated one. Hypoxia-stressed mussels seemed to have a higher specific enzyme activity than control mussols. The response curve of enzyme-specific activity with increasing detergent concentration asymptoted, suggesting that a threshold concentration of Triton X-100 was required to solubilize the lysosomal membranes completely. The results indicate that the filtration technique is suitable for determination of lysosomal integrity in lysosome-rich tissues and may be useful as a biomarker in environmental monitoring
\end{abstract}

KEY WORDS: Lysosomes - Lysosomal latency - Lysosomal stress response - Enzyme activity

\section{INTRODUCTION}

In many organisms cellular responses to environmental stress may be detected before stress becomes apparent in the physiology of the whole organism. Cellular stress responses may provide a rapid and sensitive indicator of environmental alterations (Moore 1980) and potentially can provide direct evidence of biological deterioration and the probable cause(s) of biological damage (Moore 1990).

One cellular stress response, lysosomal stress response, involves the partial damage and destabilization of lysosomal membranes, resulting in increased membrane permeability and the subsequent freeing of 'latent' acid hydrolases (Allison 1969, Pietras et al. 1975, Szego et al. 1977) with the possible 'leakage' of

\footnotetext{
- Present address: PO Box 167, Xiamen University, Xiamen, China
}

these hydrolases into the cytoplasm (Szego 1975). The lysosomal stress response is a generalized response to a wide range of physical, chemical, and biological stressors (Moore 1980), and has been quantitatively related to the degree of stress experienced by an organism (Bayne et al. 1976, Moore \& Stebbing 1976. Moore et al. 1978)

Lysosomes are degradative organelles that exist in almost all eukaryotic cells. They contain large amounts of hydrolytic enzymes that are responsible for intracellular digestion of endogenous cellular components and endocytosed exogenous substances. In the digestive cells of normal mussels these hydrolases are bound within the lysosome (termed 'latent'), and are only accessible by substrates that enter the lysosome by vacuolar fusion or membrane transport (Moore 1980).

The lysosomes in the digestive cells of a stressed organism are more fragile (Abraham et al. 1967) and permeable to substrates (Moore 1980) than lysosomes 
in an unstressed organism. Stressed lysosomes are more easily disrupted by mechanical trauma, osmotic shock, the action of detergents, or changes in the ion concentration of a solution, which occur during extraction of the lysosomes from cells.

The aim of this study is to develop a reliable, simple and inexpensive biochemical assay that can be used for routine marine environmental monitoring. This investigation used both cold filtration and cold centrifuge fractionation methods to prepare lysosomeenriched fractions in order to protect lysosomal membranes from temperature-induced rupture. A biochemical enzyme assay was then employed to determine the stability of the lysosomal membranes for each technique. This was perhaps the first time in the study of Iysosomal membrane stability that filtration, a relatively unsophisticated technique, was used to prepare sample fluids for enzyme assay. However, our results indicate that it could be a useful, inexpensive technique for environmental monitoring.

\section{MATERIALS AND METHODS}

The molluscan digestive gland (hepatopancreas) is one of the richest sources of lysosomes in the animal kingdon (Moore \& Viarengo 1987). The mussel Mytilus edulis is a sessile bivalve mollusc living in the subtidal zone of coastal waters. In the United States, it is used by the Mussel Watch program as a marine environmental monitoring organism because it accumulates poliutants in its body tissues (Goldberg et al. 1978).

Preparation of filtered and fractionated samples. Mytilus edulis 50 to $55 \mathrm{~mm}$ in length were collected from the coast near Gaviota, California, USA. They were held for $40 \mathrm{~d}$ in flowing aerated seawater $\left(15^{\circ} \mathrm{C}\right)$ before the experiment. Five days prior to being sacrificed 7 mussels were either exposed to air in a humid place at a daytime temperature of 21 to $22^{\circ} \mathrm{C}$ (hypoxic treatment), or maintained in flowing aerated seawater (control treatment). Because only 7 hypoxic mussels or 7 control mussels could be analyzed on a given day, exposures of 7 mussels were started on alternating days. Both treatments were repeated 5 times (i.e. 5 batches). After exposure the digestive glands of 7 mussels were dissected, cleaned of gonadal tissues and blotted dry (this and all subsequent steps were carried out below $5^{\circ} \mathrm{C}$ ), and then minced together in 20 volumes of cold $0.25 \mathrm{M}$ sucrose solution buffered with citric acid/0.1 $\mathrm{M} \mathrm{K}_{2} \mathrm{HPO}_{4}$ (pH 8.0). The sample was transferred to an all-glass homogenizer and homogenized by hand for 12 strokes, then divided into 2 parts. One half was gravity filtered through no. 1 Whatman filter paper (filter apparatus was placed in refrigerator for the $4 \mathrm{~h}$ it took to complete filtration), and the filtrate retained for enzyme assay. The other half was fractionated by centrifugation at $1000 \times g$ for $10 \mathrm{~min}, 3300 \times \mathrm{g}$ for $10 \mathrm{~min}$, and then $16300 \times \mathrm{g}$ for 20 min (Griffiths 1975). The supernatant was discarded and the pellet was resuspended in $2.0 \mathrm{ml}$, cold bufferedsucrose solution and recentrifuged at $3300 \times g$ for $10 \mathrm{~min}$. The resulting clear supernatant was assayed for enzyme activity.

Assay of acid phosphatase with p-nitrophenyl phosphate. The enzyme assay filtered and fractionated preparations were treated similarly. The assay mixture consisted of $2 \mathrm{mM}$ p-nitrophenyl phosphate, $0.1 \mathrm{M}$ acetate/acetic acid buffer ( $\mathrm{pH} 5.0), 0.25 \mathrm{M}$ sucrose and $1 \mathrm{mM}$ EDTA. Triton $\mathrm{X}-100$ was then added to the assay mixture bringing the final concentrations of detergent to $0,0.0625,0.125$, and $0.250 \mathrm{mg} \mathrm{ml}^{-1}$. The enzyme reaction was carried out at room temperature (21 to $22^{\circ} \mathrm{C}$ ) and was stopped with $0.2 \mathrm{M} \mathrm{NaOH}$. Absorbance was measured on a Varian Series 634 spectrophotometer at $405 \mathrm{~nm}$. A standard curve was made using pnitrophenol (Sigma no. 104-8, lot 110H5005). Protein concentrations in the sample fluid were measured by the Lowry method (Sigma protein assay kit, procedure no. p5656). Each absorbance data point is the average from 2 replicate assay vials, and their relative error was $<1 \%$.

Determination of lysosomal membrane stability involves several aspects. These are free enzyme activity $\left(E_{\mathrm{f}}\right)$, membrane-bound enzyme activity $\left(E_{\mathrm{b}}\right)$, tatal enzyme activity $\left(E_{t}\right)$, and lysosomal membrane-linked latency $(L)$. Enzyme activity in the primary sample fluid is defined as free enzyme activity $E_{f}$. Triton X-100, a non-ionic detergent, when added to an aliquot of the sample fluid, will solubilize lysosomal membranes and release almost all the membrane-bound enzymes (Hollander 1971). The enzyme activity of the sample fluid measured after the detergent treatment is defined as total enzyme activity, $E_{\mathrm{t}}$, where $E_{\mathrm{t}}=E_{\mathrm{f}}+E_{\mathrm{b}}$. Latency, $L_{\mathrm{r}}$ is the percentage of total enzymes that are bound (latent): $L=E_{\mathrm{b}} / E_{l} \times 100 \%$. Because $E_{\mathrm{b}}$ cannot be measured directly it was calculated using $L=\left(E_{\mathrm{t}}-E_{\mathrm{f}}\right) / E_{\mathrm{t}} \times$ $100 \%$. One can infer that latency is the proportion of lysosomal membranes that maintain their integrity. In this investigation, $L$. rather than $E_{f}$, was used as the measure of stress on the mussels.

\section{RESULTS}

Membrane-linked latency was reduced in the hypoxia-stressed mussels (Table 1). The difference in latency between hypoxic and control mussels was significant $(p<0.0007)$ in the filtered preparations, but not in the centrifuge fractionated ones. The latency in filtered preparations was much lower than that of fractionated preparations, $18 \%$ and $65 \%$, respectively. 
Table 1. Effect of hypoxia and sample preparation method on membrane-linked latency of lysosomes (mean $\pm 1 \mathrm{SE}$ ) in the digestive cells of Mytilus edulis. All experiments were repeated 5 times, except the control fractionated preparations

$$
(n=3)
$$

\begin{tabular}{|lccc|}
\hline Preparation & \multicolumn{2}{c}{$\begin{array}{c}\text { Membrane-linked latency }(\%) \\
\text { Hypoxia }\end{array}$} & Control \\
\hline Filtered & $13.5 \pm 1.02$ & $21.7 \pm 1.16$ & 0.0007 \\
Fractionated & $63.7 \pm 1.60$ & $65.7 \pm 0.52$ & 0.3891 \\
\hline
\end{tabular}

Specific enzyme activity was higher in the stressed mussels than in the control ones (Fig. 1). While the difference was not significant, it was consistent across preparations. There was a significant difference in $E_{f}$ between the stressed and control mussels in the filtered preparations ( $0 \mathrm{mg}$ Triton $\mathrm{X}-100 \mathrm{ml}^{-1}$ ). $E_{\mathrm{f}}$ activities and $E_{\mathrm{t}}$ activities, measured where the activity curves asymptote $\left(0.25 \mathrm{mg}\right.$ Triton X-100 $\left.\mathrm{ml}^{-1}\right)$, were higher in the filtered preparations than in centrifugefractionated ones. The low $E_{1}$ in the fractionated preparations produced curves with more of an S-shape.

\section{DISCUSSION}

Moore (1976) demonstrated hyperthermia-induced destabilization of lysosomal membranes in the digestive cells of Mytilus edulis. He used a cytochemical technique with a microscopic photometer to quantify the increased permeability of lysosomal membranes in stressed mussels. The equipment used is not available in many marine biological laboratories. Attempts to develop other techniques to measure the effects of stress on lysosomes have been carried out. For instance, Koehn et al. (1980) and Bayne et al. (1981) investigated the effect of increased salinity on lysosomal integrity in $M$. edulis. They used a technique involving a gradient of osmotic potentials to disrupt purified lysosomes. The stressed mussels showed an increase in specific activity of hexosaminidase in the crude supernatant of a centrifuged tissue sample (Bayne et al. 1981). However, many of the larger lysosomes were mechanically disrupted during the preparatory process, making it difficult to separate the environmental effects. Patel \& Patel (1985) studied the effect of environmental parameters on lysosomal marker enzymes in the tropical blood clam Anadara granosa using a conventional biochemical enzyme assay, and showed a decline in $E_{\mathrm{f}}$ and $E_{\mathrm{t}}$ in both arylsulfatase and acid phosphatase. They found that 'lysosomal latency could not be demonstrated unequivocally in some cases by the standard latency test procedure of adding detergent'.

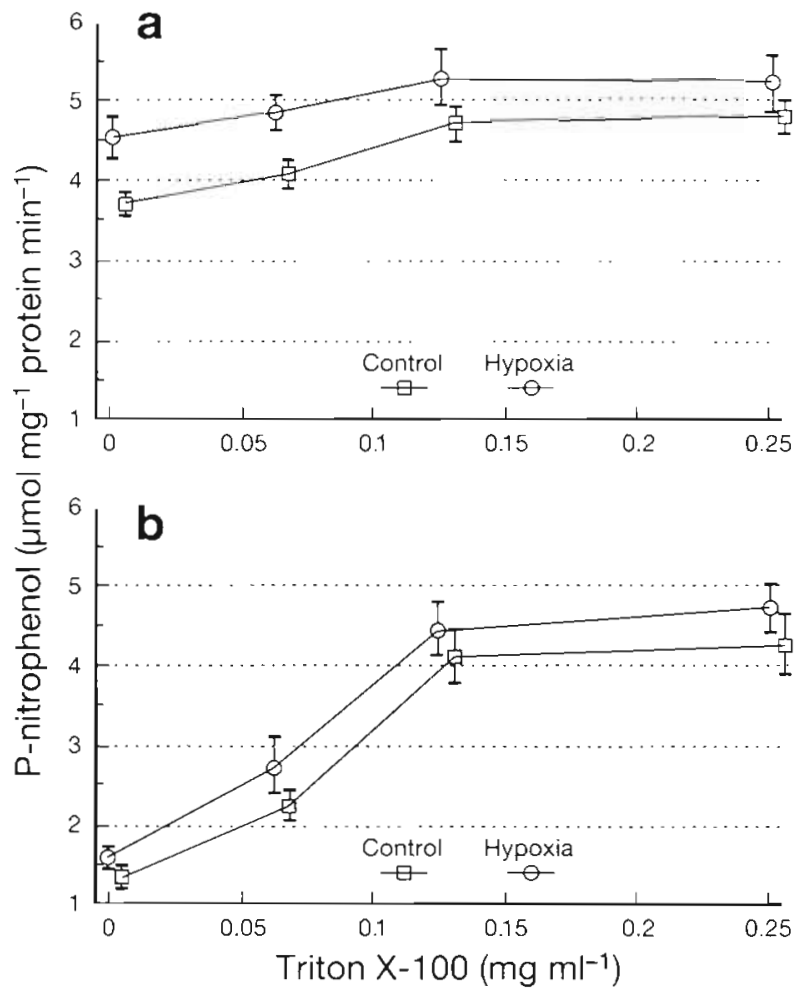

Fig. 1 (a) Filtered and (b) centrifuge-fractionated specific enzyme activities for acid p-nitrophenyl phosphatase measured at different concentrations of Triton $X-100$. Control error bars are offset horizontally for clarity. Mean $\pm 1 \mathrm{SE}_{;}$ $n=5$, except control fractionated preparations, where $n=3$

In this experiment there was a non-significant increase in specific enzyme activity in the stressed mussels. While the decline in latency with stress has been confirmed by several researchers, the effect on specific enzyme activity warrants further investigation.

Koehn et al. (1980) and Bayne et al. (1981) obtained S-shaped enzyme relative activity curves (latency curves). They interpreted this relationship as an increase in the proportion of partially destabilized lysosomes. In the present experiment a gradient of detergent was used to disrupt lysosomes, and an Sshaped enzyme-specific activity curve was obtained (Fig. 1). The threshold for complete solubilization of lysosomal membranes appeared to be $0.125 \mathrm{mg}$ Triton $\mathrm{X}-100 \mathrm{ml}^{-1}$.

Moore et al. (1979) exposed 2 species of marine bivalves to air at $20^{\circ} \mathrm{C}$ for $2 \mathrm{~d}$ at which time there was a decline in the latency of lysosomal $N$-acetyl- $\beta$-hexosaminidase and $\beta$-glucuronidase. This was in contrast to the $5 \mathrm{~d}$ necessary to induce a change in latency in the present experiment. Stressed animals should have lower lysosomal latency because membranes become more permeable and fragile when stressed. While permeability and fragility of lysosomal membranes are 
both affected by stress to the organism, they are measured differently. Permeability is measured using microscopic cytochemical techniques. Fragility is determined using biochemical techniques. The cytochemical technique used by Moore et al. (1979) appears to be more sensitive than the biochemical assay used in this experiment.

Filtration may be more effective than centrifugation for determining changes in latency. During homogenization and centrifugation some lysosomes, made fragile by hypoxia, ruptured and their enzymes diffused into the solution and ended up in the supernatant after the third step in centrifugation, while most of the unbroken lysosomes ended up in the pellet after the third step, which was then used for enzyme assay. After the third step of centrifugation, the supernatant, which contained all of the ruptured lysosomes, was discarded. It can be inferred that most of the cell components which contribute to hydrolysis and the enzymes released from disrupted lysosomes were discarded. Free enzyme activity was thus higher using the filtration process because almost all of these diffused enzymes (except some adsorbed to the filter paper) together with other cell components, unbroken cells and tiny fragments of tissue passed through the filter paper, contributing to the estimate of $E_{\mathrm{f}}$. The enzyme activity attributed to the hypoxia-affected lysosome was not lost in the process of filtration, therefore one can see the difference between hypoxic and control mussels. In the filtrate, the increased enzyme activity attributed to hypoxia stress (Fig. 1a) was only equivalent to a small portion of free enzyme activity. This was why the sensitivity of the filtration method was much lower than the cytochemical method. In this experiment the latency of the fractionated preparations was much higher than that of the filtered preparations $(60$ vs $20 \%$ ). The fractionated preparation was useful in the study of the mechanics of the lysosome, but not for the assessment of environmental stresses. This was because a quantity of the free enzymes resulting from stress to the organism was discarded using the centrifuge fractionation method. This result suggests that when using a centrifuge fractionation technique to study lysosomal stress response, particular attention must be paid to the stress-sensitive component present in the supernatant during centrifugation.

In conclusion, the filtration method was suitable for the determination of lysosomal latency in molluscan digestive tissue, where the cells are extremely rich in lysosomes. This relatively simple and rapid technique may lend itself for use as a biomarker of lysosomal integrity and animal health in marine environmental monitoring studies. Testing with other stressors, including heavy metals and other xenobiotics, will be required to further validate the method.
Acknowledgements. The authors thank Drs R. J. Schmitt, S. J Holbrook, C. W. Osenberg, B. Mahall, G. Cherry, and M. N. Moore, and Profs houze Huang, fulong $C a$ i, and suli Chen for their enthusiastic support and guidance. This research was supported in part by the University of California Coastal Toxicology Program and the Minerals Management Service, U.S. Dept of the Interior, under MMS Agreement No. 14-35-000130471 (The Southern California Educational Initiative). The views and conclusions contained in this document are those of the authors and should not be interpreted as necessarily representing the official policies, either express or implied, of the the U.S. Government

\section{LITERATURE CITED}

Abraham, R., Colberg, L., Grasso, P. (1967). Hepatic response to lysosomal effects of hypoxia, neutral red and chloroquine. Nature 215: 194-196

Allison, A. C. (1969). Lysosomes and cancer. In: Dingle, J. T. Fell, J. B. (eds.) Lysosomes in biology and pathology, Vol. 2. Elsevier, Amsterdam, p. 176-204

Bayne, B. L., Livingstone, D. R., Moore, M. N., Widdows, J. (1976). A cytochemical and biochemical index of stress in Mytilus edulis L. Mar. Pollut. Bull. 7: 221-224

Bayne, B. L., Moore, M. N., Koehn, R. K. (1981). Lysosomes and the response by Mytilus edulis $\mathrm{L}$. to an increase in salinity. Mar. Biol. Lett. 2: 193-204

Goldberg, E. D., Bowen, V. T., Farrington, J. W., Harvey, G., Martin, J. H., Parker, P. L., Riseborough, R. W., Robertson, W., Schneider, E., Gamble, E. (1978). The mussel watch. Environ. Conserv. 5: 101-125

Griffiths, A. (1975). Techniques of centrifugation. In: Williams, B. L., Wilson, K. (eds.) A biologist's guide to principles and techniques of practical biochemistry. Edward Arnold, London, p. 33

Hollander, V. P. (1971). Acid phosphatase. In: Boyer, P. D. (ed.) Enzymes, Vol. 4. Academic Press, New York, p. 454-485

Koehn, R. K., Bayne, B. L., Moore, M. N., Siebenaller, J. F. (1980). Salinity related physiological and genetic differences between populations of Mytilus edulis. Biol. J. Linn. Soc. $14: 319$

Moore, M. N. (1976). Cytochemical demonstration of latency of lysosomal hydrolases in digestive cells of the common mussel Mytilus edulis, and changes induced by thermal stress. Cell Tissue Res. 175: 279-287

Moore, M. N. (1980). Cytochemical determination of cellular responses to environmental stressors in marine organisms. Rapp. P.-v. Réun. Cons. int. Explor. Mer 179: 7-15

Moore, M. N. (1990). Lysosomal cytochemistry in marine environmental monitoring. Histochem. J. 22:187-191

Moore, M. N., Lowe, D. M., Fieth, P. E. M. (1978). Lysosomal responses to experimentally injected anthracene in the digestive cells of Mytilus edulis. Mar. Biol. 48: 297-302

Moore, M. N., Lowe, D. M., Moore, S. L. (1979). Induction of lysosomal destabilisation in marine bivalve molluscs exposed to air. Mar. Biol. Lett. 1. 47-57

Moore, M. N., Stebbing, A. R. D. (1976). The quantitative cytochemical effects of three metal ions on a lysosomal hydrolase of a hydroid. J. mar. biol. Ass. U.K. 56: 995-1005

Moore, M. N., Viarengo, A. (1987). Lysosomal membrane fragility and catabolism of cytosolic proteins: evidence for a direct relationship. Experientia 43: 320-322

Patel. S., Patel, B. (1985). Effect of evironmental parameters on lysosomal marker enzymes in the tropical blood clam Anadara granosa. Mar. Biol. 85: 245-252 
Pietras, R. J., Seeler, B. J., Szego, C. M. (1975). Influence of antidiuretic hormone on release of lysosomal hydrolase at mucosal surface of the epithelial cells from urinary bladder. Nature 257: 493-495

Szego, C. M. (1975). Lysosomal function in nucleocytoplasmic communication. In: Dingle, J. T., Fell, J. B. (eds.) Lyso-

This article was presented by S. N. Luoma, Menlo Park, California, USA somes in biology and pathology, Vol. 4. Elsevier, Amsterdam, p. 385-477

Szego, C. M., Nazareno, M. B., Porter, D. D. (1977). Estradiolinduced redistribution of lysosomal protens in rat preputial gland: evidence from immunologic probes. J. Cell Biol. 73: 354-365

Manuscript first received: May 12,1993 Revised version accepted. August 19, 1994 